\title{
A Genetic Association Study of MTHFR C677T Polymorphism with Risk of Metabolic Syndrome: A Systematic Review and Meta-Analysis
}

Soheil Azizi' ${ }^{1}$, Amir Shamshirian ${ }^{2}$, Reza Alizadeh-Navaei ${ }^{3}$, Hamed Jafarpour ${ }^{2}$, Zatollah Asemi ${ }^{4}$, Omid Reza Tamtaji ${ }^{5}$, Mohammad Sadegh Vaziri ${ }^{6}$, Reza Homayounfar ${ }^{7}$, Arash Rezaei Shahmirzadi ${ }^{8}$, Reza Alipoor ${ }^{6,7}$

\footnotetext{
${ }^{1}$ Department of Laboratory Sciences, Faculty of Paramedicine, Mazandaran University of Medical Sciences, Sari, Iran

${ }^{2}$ Student Research Committee, Mazandaran University of Medical Sciences, Sari, Iran

${ }^{3}$ Gastrointestinal Cancer Research Center, Mazandaran University of Medical Sciences, Sari, Iran

${ }^{4}$ Research Center for Biochemistry and Nutrition in Metabolic Diseases, Kashan University of Medical

Sciences, Kashan, Iran

${ }^{5}$ Physiology Research Center, Kashan University of Medical Sciences, Kashan, Iran

${ }^{6}$ Student Research Committee, Hormozgan University of Medical Sciences, Bandar Abbas, Iran

${ }^{7}$ Non-Communicable Disease Research Center, Fasa University of Medical Sciences, Fasa, Iran

${ }^{8}$ Student Research Committee, Golestan University of Medical Sciences, Gorgan, Iran
}

\begin{abstract}
Methylenetetrahydrofolate reductase (MTHFR) is an enzyme that plays a crucial role as a methyl-group donor in demethylation of homocysteine. The aim of this systematic review and meta-analysis was to study the relationship between MTHFR gene polymorphism and metabolic syndrome (MS). We used search engines and databases such as Science Direct, Google Scholar, Embase, Cochrane Library, and PubMed to identify eligible studies up to 2018. The articles were studied based on keywords including MTHFR, mutation, variant, and polymorphism in combination with MS. Data was analyzed using Comprehensive Meta-Analysis version 2.2.064 software. After extracting the data from seven articles, the total number of subjects was 1280 in the patient group and 1374 in the control group. The odds ratio was estimated to be 1.078 for the allele model of $\mathrm{T}$ vs. C (95\% confidence interval [CI]: 1.626-0.715), 1.157 for the allele model of CC vs. CT (95\% CI: 0.829-1.615), 1.020 for the allele model of CT + TT vs. CC (95\% CI: 1.611-0.646) and 0.799 for the allele model of TT vs. CC + CT (95\% CI: $1.185-$ $0.539)$. As well, the results showed no statistically significant correlation between polymorphism genotypes of the MTHFR gene and MS $(\mathrm{P}<0.05)$. In general, this study showed that the presence of C677T polymorphism in the MTHFR gene has no effect on the incidence of MS.
\end{abstract} [GMJ.2019;8:e1472] DOI:10.31661/gmj.v8i0.1472

Keywords: MTHFR; Metabolic Syndrome; Polymorphism; Variant; Meta-Analysis; Methylenetetrahydrofolate Reductase

\section{Introduction}

$\mathrm{M}$ ethylenetetrahydrofolate $(M T H F R)$ is an enzyme that plays an important role as a methyl-group donor in de-

\section{GMJ}

Copyright $($ 2019, Galen Medical Journal. This is an open-access article distributed under the terms of the Creative Commons Attribution 4.0 International License (http://creativecommons.org/licenses/by/4.0/) Email:info@gmj.ir methylation of homocysteine [1]. Due to the incidence of C677T mutation in the MTHFR gene, thymine is replaced by cytosine, followed by the translation of valine instead of alanine in the structure of the produced en-

\footnotetext{
Correspondence to:

Reza Alipoor, Student Research Committee, Fasa Uni-

versity of Medical Sciences, Fasa, Iran

Telephone Number: +989174462124

Email Address: Reza.alipoor@hums.ac.ir
} 
zyme, resulting in the formation of a temperature-sensitive enzyme and thus reducing its activity [2]. The set of these changes increases the concentration of homocysteine and endothelial dysfunction and accelerates the oxidation of lipoproteins [3]. It has been observed that the levels of homocysteine increase in patients with diabetes mellitus (DM) $[4,5]$ and hypertension $[6,7]$. Some studies also pointed to the relationship between hyperhomocysteinemia and insulin resistance [8-10]. This relationship can be partially justified in light of the correlation of C677T polymorphism (occurring in the MTHFR gene) with hypertension [11], DM [12, 13], and diabetic nephropathy [14]. In recent years, there has been a significant relationship between MTHFR and metabolic syndrome (MS) in certain groups of people with type 2 DM [15] and schizophrenia [16], but these studies have very different results in relation between MTHFR and MS, and no comprehensive study has been done to summarize these outcomes in patients with MS. Regarding the high prevalence of MS and the role of genetic factors in the disease [17], determining the relationship between MTHFR polymorphism and MS can be helpful. In this way, people who are genetically predisposed to the disease can be identified more quickly to fulfill preventive interventions. The aim of this systematic review and meta-analysis was to study the relationship between MTHFR gene polymorphism and MS.

\section{Search Strategies}

Search engines and databases including PubMed, Embase, ScienceDirect, Cochrane Library, and Google Scholar were searched to find all English articles up to 2018. The related keywords were extracted using the Medical Subject Heading (MeSH), containing "MTHFR," "mutation," "variant," and "polymorphism" in combination with "MS." Also, the search was also conducted in the language restriction. Two of the authors reviewed the articles considering the inclusion and exclusion criteria, and the third author reviewed controversies to take the final decision. All articles aiming to investigate the relationship between MTHFR polymorphisms and MS were introduced into the study. Selected arti- cles for meta-analysis had the following features: evaluation of the relationship between MTHFR gene and MS, number of subjects in case and control groups, access to distribution of genotypes and alleles in case and control groups, considering 95\% confidence interval (CI) to estimate odds ratio (OR), original research articles, randomized and controlled articles, and considering gene polymorphism as the main independent variable. Also, when several investigations were conducted on the same population, the latest study was selected to enter into the meta-analysis. The standard information form was used for data collection. Form information included the author name, publication year, study location, genotype type, total number of subjects in case and control groups, genotype distribution in the case and control groups, and the frequency of the dominant allele in both case and control groups. Two of the authors performed the process of extracting information from articles. Hardy-Weinberg equilibrium, genotyping methods qualification, controls source, sample size, and cases representativeness, were examined with a total score of 10 in this scoring. This checklist had been used in previous studies. Besides, scores zero to four were categorized as a weak study, five to seven as an average study, and eight to 10 as a strong article. The allele frequency for gene polymorphism was determined in each study using the allele counting method. OR with $95 \%$ CI was used to evaluate the power of correlation between MTHFR gene and MS, followed by the allele model (C vs. T), multiplicative model (CC vs. TT), the dominant model $(\mathrm{CC}+\mathrm{CT}$ vs. TT), and recessive model $(\mathrm{CC}$ vs. $\mathrm{CT}+\mathrm{TT})$. Heterogeneity was calculated using measurement test and the random effects model. The I-square (I2) index of 25, 50 , and 75 percent showed lower, moderate, and high levels of heterogeneity, respectively. The bias of published articles was examined using a funnel plot versus standard error (SE). Publication bias was evaluated using both Begg's funnel plot and Egger's linear regression test. Because of significant heterogeneity of the results $(I 2>30 \%)$, the random effects model, which takes the diversity of the studies into account, was used. All analyses were performed by Comprehensive Meta-Analysis 
version 2.2.064 (CMA) software. $A$ P-value of less than 0.05 was considered as a significance level.

\section{Results}

In total, 95 studies were systematically reviewed. Some studies were excluded because of the similarity of the studied samples $(n=69)$, the inappropriateness of the samples and the failure to consider the MS as the main variable $(n=22)$, and inadequate information on alleles $(\mathrm{n}=4)$. Finally, seven papers [18-23] were entered into the meta-analysis. Studies characteristics are presented in Table- 1 . To evaluate the publication bias of studies entered into the meta-analysis, Egger's test and Begg's funnel plot were used (Table-2). In all genetic models, the appearance of the shape of the funnel plots was symmetrical (Figure-1). We used Egger's test to provide the statistical evidence of funnel plot. The findings of the research showed that there is no publication bias in comparison models. Heterogeneities

Table 1. Studies Characteristics and Distribution of C677T Polymorphism

\begin{tabular}{|c|c|c|c|c|c|c|c|c|}
\hline \multirow{2}{*}{\multicolumn{2}{|c|}{$\begin{array}{c}\text { Variables } \\
\text { Chedraui } \text { et al. }\end{array}$}} & \multicolumn{7}{|c|}{ Authors } \\
\hline & & \multirow{2}{*}{$\begin{array}{c}\text { Chen et al. } \\
{[18]}\end{array}$} & \multirow{2}{*}{$\begin{array}{c}\begin{array}{c}\text { Fakhrzadeh } \\
\text { et al. }\end{array} \\
{[19]}\end{array}$} & \multirow{2}{*}{$\begin{array}{c}\text { Kang } \text { et al. } \\
{[20]}\end{array}$} & \multirow{2}{*}{$\begin{array}{c}\begin{array}{c}\text { Russo } \\
\text { et al. }\end{array} \\
{[21]}\end{array}$} & \multirow{2}{*}{$\begin{array}{c}\begin{array}{c}\text { Yang } \boldsymbol{e t} \\
\text { al. }\end{array} \\
{[15]}\end{array}$} & \multicolumn{2}{|l|}{$\begin{array}{c}\text { Zeman } \\
\text { et al. }\end{array}$} \\
\hline Refer & & & & & & & {$[22]$} & {$[23]$} \\
\hline $\mathrm{Ye}$ & & 2012 & 2008 & 2009 & 2009 & 2002 & 2011 & 2008 \\
\hline \multicolumn{2}{|c|}{ County of region } & Ecuador & China & Iran & Korea & Italy & China & Prague \\
\hline \multicolumn{2}{|c|}{ Study design } & PB & PB & PB & HP & $\mathrm{HB}$ & PB & PB \\
\hline \multicolumn{2}{|c|}{$\begin{array}{l}\text { Genotyping } \\
\text { method }\end{array}$} & PCR & PCR & PCR & PCR & PCR & PCR & PCR \\
\hline \multicolumn{2}{|c|}{ Cases } & 103 & 118 & 150 & 110 & 50 & 692 & 57 \\
\hline \multicolumn{2}{|c|}{ Controls } & 89 & 95 & 76 & 145 & 50 & 878 & 41 \\
\hline & $\mathrm{CC}$ & 48 & 34 & 102 & 36 & 36 & 129 & 30 \\
\hline \multirow[t]{3}{*}{ Cases } & CT & 45 & 61 & 38 & 60 & 49 & 335 & 19 \\
\hline & TT & 10 & 23 & 10 & 14 & 21 & 228 & 8 \\
\hline & $\mathbf{C C}$ & 38 & 57 & 36 & 51 & 31 & 202 & 16 \\
\hline \multirow[t]{2}{*}{ Control } & CT & 37 & 30 & 31 & 74 & 51 & 431 & 17 \\
\hline & TT & 14 & 8 & 9 & 20 & 18 & 245 & 18 \\
\hline \multicolumn{2}{|c|}{$\begin{array}{l}\text { Minor allele } \\
\text { frequency } \\
\text { (Cases) }\end{array}$} & 0.315 & 0.466 & 0.193 & 0.4 & 0.429 & 0.571 & 0.307 \\
\hline \multicolumn{2}{|c|}{$\begin{array}{l}\text { Minor allele } \\
\text { frequency } \\
\text { (Controls) }\end{array}$} & 0.365 & 0.242 & 0.322 & 0.393 & 0.435 & 0.524 & 0.519 \\
\hline \multicolumn{2}{|c|}{ HWE (P-value) } & 0.329 & 0.173 & 0.562 & 0.402 & 0.707 & 0.638 & 0.017 \\
\hline
\end{tabular}


Table 2. Statistics to Test Publication Bias and Heterogeneity in the Meta-Analysis

\begin{tabular}{|c|c|c|c|c|c|c|c|}
\hline \multirow{2}{*}{$\begin{array}{c}\text { Comparison } \\
\text { Model }\end{array}$} & \multicolumn{3}{|c|}{ Egger's regression analysis } & \multicolumn{3}{|c|}{ Heterogeneity analysis } & \multirow{2}{*}{$\begin{array}{l}\text { Model used } \\
\text { for the meta- } \\
\text { analysis }\end{array}$} \\
\hline & Intercept & $\begin{array}{c}\text { confidence } \\
\text { interval }\end{array}$ & P-value & $Q$-value & $P_{\text {(Heterogeneity) }}$ & $I^{2}(\%)$ & \\
\hline T vs. C & -1.05 & -8.21 to 6.10 & 0.670 & 24.27 & $<0.001$ & 83.521 & Random \\
\hline TT vs. CC & -1.26 & -4.52 to 1.99 & 0.362 & 18.66 & 0.005 & 67.852 & Random \\
\hline CT Vs. CC & -0.60 & -5.14 to 3.93 & 0.745 & 16.16 & 0.013 & 62.880 & Random \\
\hline $\begin{array}{c}\mathbf{C T}+\mathbf{T T} \text { vs. } \\
\mathbf{C C}\end{array}$ & -1.79 & -7.98 to 4.39 & 0.489 & 33.68 & $<0.001$ & 82.190 & Random \\
\hline $\begin{array}{c}\text { TT vs. } \\
\text { CT }+ \text { CC }\end{array}$ & -2.00 & -3.97 to 2.62 & 0.046 & 15.49 & 0.017 & 61.286 & Random \\
\hline
\end{tabular}
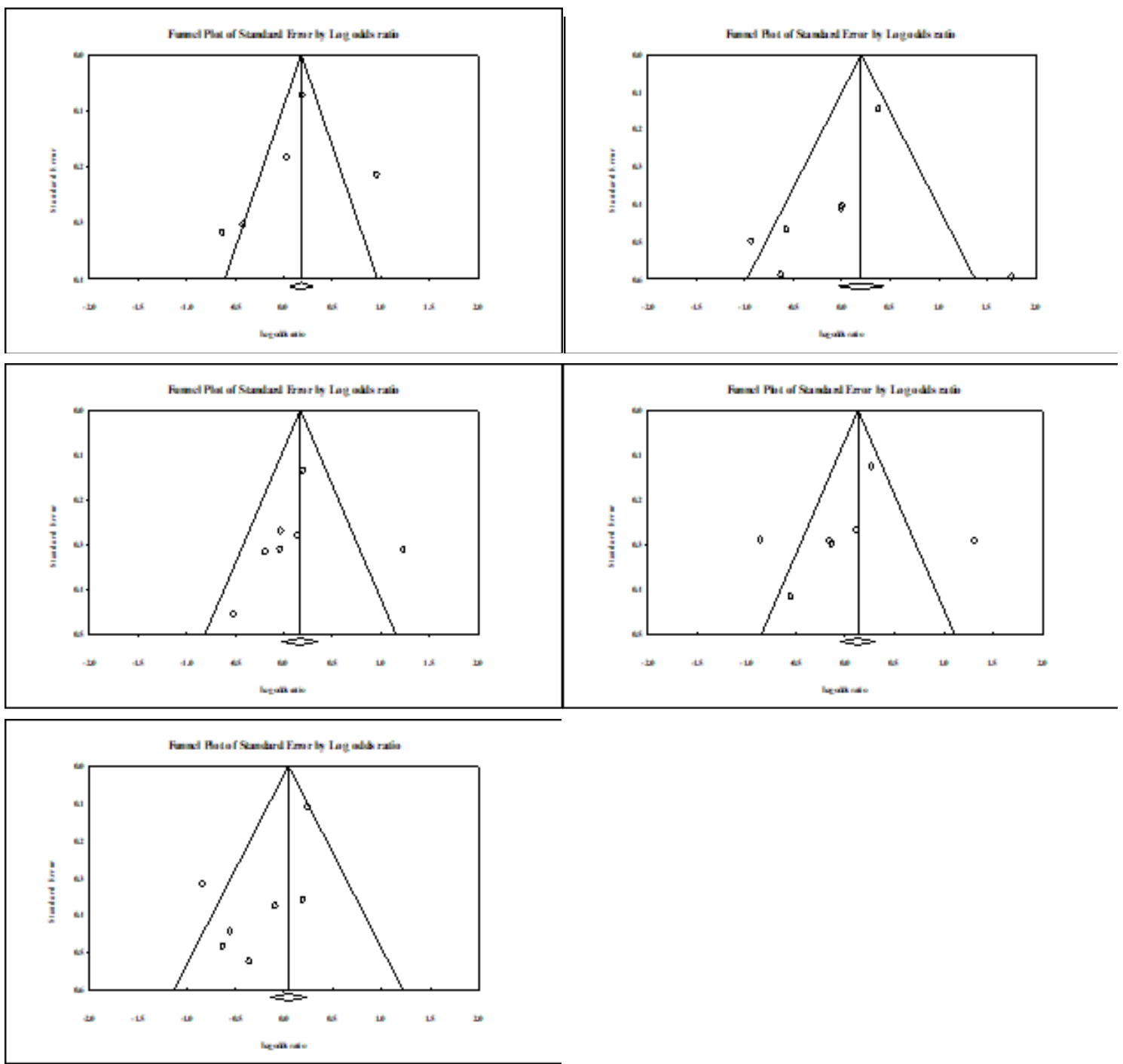

Figure 1. Funnel plot of standard error by log odds ratio 
were evaluated by using an $I 2$ test and $Q$-test. Heterogeneity was observed in all the models, i.e., allele (T vs. C), homozygous (TT vs. $\mathrm{CC}$ ), heterozygous (CT vs. CC), dominant $(\mathrm{CT}+\mathrm{TT}$ vs. $\mathrm{CC}$ ), and recessive (TT vs. CT + CC) genotype model, which were included for the meta-analysis. Therefore, the random effects model, which takes the diversity of the studies into account was used for data analysis. Meta-analysis of C677T polymorphism in the MTHFR gene and MS in total consisted of six case-control studies and one cohort study. Available studies in the meta-analysis were used to evaluation of the relationship between MTHFR polymorphism and MS. In general, these studies showed that the total number of subjects was 1280 in the MS patient group and 1374 in the healthy control group. According to the findings of this study (Figure-2), there was no significant relationship between $M T H$ FR $677 \mathrm{C}>\mathrm{T}$ polymorphism and MS in the allele model ( $\mathrm{T}$ vs. $\mathrm{C}$ : $\mathrm{P}=0.720 ; \mathrm{OR}=1.078$, $95 \% \mathrm{CI}=0.715$ to 1.626$)$, in the homozygous model (TT vs. CC: $\mathrm{P}=0.987, \mathrm{OR}=1.004$, $95 \% \mathrm{CI}=0.596$ to 1.693 ), in the heterozygous model (CT vs. $\mathrm{CC}: \mathrm{P}=0.390, \mathrm{OR}=1.157$, $95 \% \mathrm{CI}=0.829$ to 1.615$)$, in the dominant model $(\mathrm{CT}+\mathrm{TT}$ vs. $\mathrm{CC}: \mathrm{P}=0.931, \mathrm{OR}=$ $1.020,95 \% \mathrm{CI}=0.646$ to 1.611$)$ and in the recessive model (TT vs. $\mathrm{CT}+\mathrm{CC}: \mathrm{P}=0.265$; $\mathrm{OR}=0.799,95 \% \mathrm{CI}=0.539$ to 1.185 ).

\section{Discussion}

According to the findings of this study, there was no significant relationship between C677T polymorphism in the MTHFR gene and MS. According to the C677T polymorphism in the MTHFR gene and MS, the result of the present study is in the same line with a study carried out by Russo et al. [15]. They indicate that there is no association between the MTHFR polymorphism and MS in patients with type 2 DM with mild hyperhomocysteinemia [15]. Yamada et al. [24] examined the possible gene responsible for the incidence of MS in 1,788 Japanese individuals, and they found no link between the MTHFR polymorphism and the prevalence of MS. However, Ellingrod et al. observed that the CT mutation in the MTH$F R$ gene predisposes those with schizophrenia taking atypical antipsychotics to MS [25].
This inconsistency is partially justified by epigenetic mechanisms. In this regard, there is a hypothesis that, in addition to inheriting the thrifty gene, epigenetic mechanisms also affect embryonic and postnatal development, and MS underlying disease including insulin resistance, local obesity, dyslipidemia, and hypertension [26]. This generation may even inherit these mechanisms from their fathers or grandparents. Since mitosis occurs during adulthood, epigenetic pathways can affect the expression of the gene in all stages of life. The MTHFR enzyme acts as a methyl-group donor for the remethylation of homocysteine and its conversion into methionine. Methionine consumes methyl group for DNA methylation, especially in $\mathrm{CpG}$ pairs. These pairs, which exist in certain regions, act as a promoter for related genes [27]. As a result, environmental and nutritional factors can affect the relationship between MTHFR and MS through these epigenetic mechanisms [28]. It is necessary to carry out comprehensive demographic studies to confirm the conclusion of the present study. According to the results, it is recommended that the necessary interventions should be promoted to change lifestyles to modify the epigenetic mechanisms in society. Flour fortification with folic acid is one of the best available actions. Hypotheses suggest that folic acid fortification can overcome the metabolic block resulting from MTHFR mutation and subsequently affect DNA methylation and gene expression. We had some limitations in this study. These limitations included lack of access to some of the main articles in English and non-English languages.

\section{Conclusion}

In general, this study showed that the presence of C677T polymorphism in the MTHFR gene has no effect on the incidence of MS. It is suggested to evaluate the effect of folic acid fortification and supplementation on the expression of the MTHFR gene, in particular, those associated with chronic diseases such as hypertension, DM, and MS.

\section{Acknowledgment}

We are sincerely thankful to our counsellors 
T vs. C

Study Name Statistics for each study Odds Lower Upper ratio limit limit Z-Value $p$-Value

$\begin{array}{llllll}\text { Chen } & 2.597 & 1.707 & 3.949 & 4.460 & 0.000\end{array}$

$\begin{array}{llllll}\text { Fakhrzadeh } & 0.531 & 0.286 & 0.989 & 1.996- & 0.046\end{array}$

$\begin{array}{llllll}\text { Kang } & 1.029 & 0.719 & 1.473 & 0.158 & 0.875\end{array}$

$\begin{array}{llllll}\text { Yang } & 1.209 & 1.049 & 1.394 & 2.627 & 0.009\end{array}$

$\begin{array}{llllll}\text { Zeman } & 0.658 & 0.363 & 1.192 & 1.381- & 0.167\end{array}$ $\begin{array}{lllll}1.078 & 0.715 & 1.626 & 0.358 & 0.720\end{array}$

TT vs. CC

Study Name

Statistics for each study

$\begin{array}{lcrrrr} & \begin{array}{c}\text { Odds } \\ \text { ratio }\end{array} & \begin{array}{r}\text { Lower } \\ \text { limit }\end{array} & \begin{array}{c}\text { Upper } \\ \text { limit }\end{array} & \text { ZValue } & \text { p-Value } \\ \text { Chedraui } & 0.565 & 0.226 & 1.414 & 1.219- & 0.223 \\ \text { Chen } & 5.750 & 1.797 & 18.403 & 2.947 & 0.003 \\ \text { Fakhrzadeh } & 0.392 & 0.148 & 1.042 & 1.877- & 0.061 \\ \text { Kang } & 0.992 & 0.443 & 2.219 & 0.020- & 0.984 \\ \text { Russo } & 1.005 & 0.455 & 2.218 & 0.011 & 0.991 \\ \text { Yang } & 1.457 & 1.096 & 1.938 & 2.588 & 0.010 \\ \text { Zeman } & 0.533 & 0.168 & 1.689 & 1.069- & 0.285 \\ & 1.004 & 0.596 & 1.693 & 0.017 & 0.987\end{array}$

CT vs. CC

Study Name

Statistics for each study

$\begin{array}{lcccrr} & \begin{array}{c}\text { Odds } \\ \text { ratio }\end{array} & \begin{array}{c}\text { Lower } \\ \text { limit }\end{array} & \begin{array}{c}\text { Upper } \\ \text { limit }\end{array} & \begin{array}{r}\text { Z-Value } \\ \text { p-Value }\end{array} \\ \text { Chedraui } & 0.963 & 0.524 & 1.769 & 0.122- & 0.903 \\ \text { Chen } & 3.409 & 1.853 & 6.270 & 3.944 & 0.000 \\ \text { Fakhrzadeh } & 0.971 & 0.573 & 1.645 & 0.111- & 0.912 \\ \text { Kang } & 1.149 & 0.665 & 1.983 & 0.498 & 0.619 \\ \text { Russo } & 0.827 & 0.445 & 1.538 & 0.599- & 0.549 \\ \text { Yang } & 1.217 & 0.936 & 1.583 & 1.464 & 0.143 \\ \text { Zeman } & 0.596 & 0.244 & 1.455 & 1.136- & 0.256 \\ & 1.157 & 0.829 & 1.615 & 0.859 & 0.390\end{array}$

CT+TT vs. CC

Study Name

Statistics for each study

Odds Lower Upper

ratio limit limit ZValue $p$-Value

$\begin{array}{llllll}\text { Chedraui } & 0.854 & 0.482 & 1.512 & 0.542- & 0.587\end{array}$

$\begin{array}{llllll}\text { Chen } & 3.706 & 2.092 & 6.566 & 4.488 & 0.000\end{array}$

$\begin{array}{llllll}\text { Fakhrzadeh } & 0.424 & 0.240 & 0.746 & 2.975- & 0.003\end{array}$

$\begin{array}{llllll}\text { Kang } & 1.115 & 0.660 & 1.884 & 0.408 & 0.683\end{array}$

$\begin{array}{llllll}\text { Russo } & 0.874 & 0.487 & 1.567 & 0.453- & 0.650\end{array}$

$\begin{array}{lllllll}\text { Yang } & 1.304 & 1.018 & 1.671 & 2.102 & 0.036\end{array}$

$\begin{array}{llllll}\text { Zenan } & 0.576 & 0.255 & 1.301 & 1.327- & 0.185\end{array}$

$\begin{array}{lllll}1.020 & 0.646 & 1.611 & 0.087 & 0.931\end{array}$

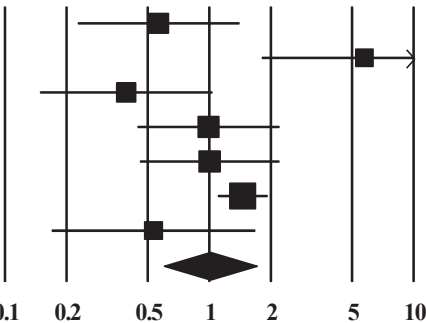

Relative

weight

$\begin{array}{lllllll}0.1 & 0.2 & 0.5 & 1 & 2 & 5 & 10\end{array}$

Odds ratio and $95 \% \mathrm{CI}$

13.56

10.80

12.82

14.98

15.16

21.78

10.90

$\begin{array}{llllllll}0.1 & 0.2 & 0.5 & 1 & 2 & 5 & 10\end{array}$

Odds ratio and $95 \% \mathrm{CI}$

weight

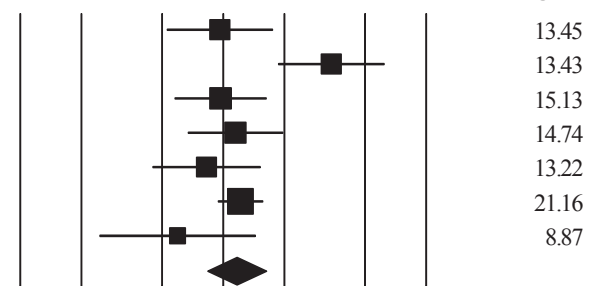

$\begin{array}{lllllll}0.1 & 0.2 & 0.5 & 1 & 2 & 5 & 10\end{array}$

Odds ratio and $95 \% \mathrm{CI}$

Relative

neight

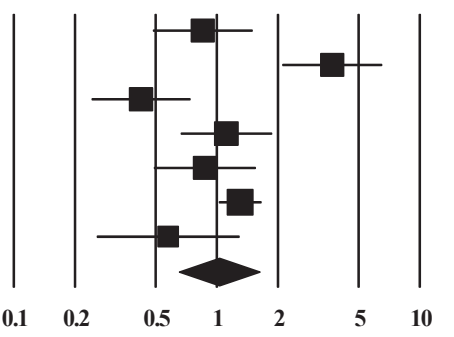

14.16

14.15

14.22

14.67

14.02

17.27

11.52

Study Name

Statistics for each study

Odds ratio and $95 \% \mathrm{CI}$

$\begin{array}{lcrrr}\begin{array}{c}\text { Odds } \\ \text { ratio }\end{array} & \begin{array}{c}\text { Lower } \\ \text { limit }\end{array} & \begin{array}{c}\text { Upper } \\ \text { limit }\end{array} & \text { ZValue } & \text { p-Value } \\ 0.576 & 0.242 & 1.370 & 1.247- & 0.212 \\ 0.434 & 0.234 & 0.807 & 2.639- & 0.008 \\ 0.532 & 0.206 & 1.370 & 1.308- & 0.191 \\ 0.911 & 0.438 & 1.897 & 0.248- & 0.804 \\ 1.211 & 0.601 & 2.442 & 0.535 & 0.593 \\ 1.270 & 1.022 & 1.576 & 2.161 & 0.031 \\ 0.698 & 0.251 & 1.944 & 0.688- & 0.492 \\ 0.799 & 0.539 & 1.185 & 1.114- & 0.265\end{array}$
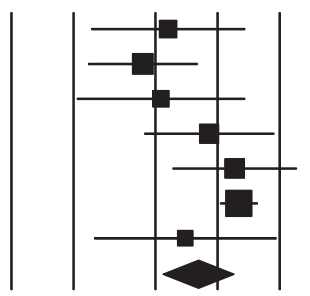

Relative

weight

11.58

15.96

10.46

13.78

14.36

24.38

Yang

Zeman

$0.799 \quad 0.539 \quad 1.185 \quad 1.114-\quad 0.265$

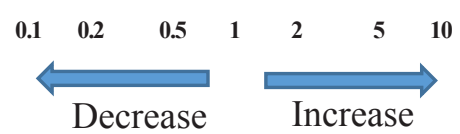

Figure 2. Forest plot analysis for assessing the overall MS risk associated with C677T polymorphism 
in Clinical Research Development Center of Shahid Mohammadi Hospital. The study was approved by the ethics committee of Hormozgan University of Medical Sciences (grant number: 970386 and ethics committee registration code: IR.HUMS.REC.1397.327). We would like to thank all the people who helped us with collecting the data and the searching works.

\section{Conflict of Interest}

None.

References

1. Maroto-Sánchez B, Lopez-Torres O, Palacios G, González-Gross M. What do we know about homocysteine and exercise? A review from the literature. Clin Chem Lab Med. 2016;54(10):1561-77.

2. Frosst P, Blom H, Milos R, Goyette P, Sheppard CA, Matthews R, et al. A candidate genetic risk factor for vascular disease: a common mutation in methylenetetrahydrofolate reductase. Nat Genet. 1995;10(1):111-3.

3. Outinen PA, Patricia C, SARGE KD, MAEDA N, HIRSH J, RIBAU J, et al. Characterization of the stress-inducing effects of homocysteine. Biochem J. 1998;332(1):213-21.

4. van Guldener C, Stehouwer CD, editors. Diabetes mellitus and hyperhomocysteinemia. Seminars in vascular medicine; 2002: Copyright (C 2002 by Thieme Medical Publishers, Inc., 333 Seventh Avenue, New York, NY 10001, USA.

5. Becker A, Smulders Y, Van Guldener C, Stehouwer C. Epidemiology of homocysteine as a risk factor in diabetes. Metab Syndr Relat Disord. 2003;1(2):105-20.

6. Li S, Zhu J, Wu L, Peng L, Luo Y, Zhao $\mathrm{Y}$, et al. The association between plasma homocysteine and ambulatory blood pressure variability in patients with untreated hypertension. Clin Chim Acta. 2018;477:328.

7. Cai W, Yin L, Yang F, Zhang L, Cheng J. Association between Hcy levels and the CBS844ins68 and MTHFR C677T polymorphisms with essential hypertension. Biomed Rep. 2014;2(6):861-8.

8. Martos R, Valle M, Morales R, Cañete R, Gavilan MI, Sánchez-Margalet V. Hyperhomocysteinemia correlates with insulin resistance and low-grade systemic inflammation in obese prepubertal children. Metabolism. 2006;55(1):72-7.
9. Lenna S, Han R, Trojanowska M. Endoplasmic reticulum stress and endothelial dysfunction. IUBMB life. 2014;66(8):530-7.

10. Giltay E, Hoogeveen E, Elbers J, Gooren L, Asscheman H, Stehouwer C. Insulin resistance is associated with elevated plasma total homocysteine levels in healthy, non-obese subjects. Atherosclerosis. 1998;139(1):197-8.

11. Ghogomu S, Ngolle N, Mouliom R, Asa B. Association between the MTHFR C677T gene polymorphism and essential hypertension in South West Cameroon. Genet Mol Res. 2016;15(1):28.

12. Zhu B, Wu X, Zhi X, Liu L, Zheng Q, Sun G. Methylenetetrahydrofolate reductase C677T polymorphism and type 2 diabetes mellitus in Chinese population: a metaanalysis of 29 case-control studies. PloS one. 2014;9(7):e102443.

13. Liew S-C, Gupta ED.

Methylenetetrahydrofolate reductase (MTHFR) C677T polymorphism: epidemiology, metabolism and the associated diseases. Eur J Med Genet. 2015;58(1):1-10.

14. Wu S, Han Y, Hu Q, Zhang X, Cui G, Li Z, et al. Effects of common polymorphisms in the MTHFR and ACE genes on diabetic peripheral neuropathy progression: a metaanalysis. Mol Neurobiol. 2017;54(4):243544.

15. Russo G, Di Benedetto A, Alessi E, Ientile R, Antico A, Nicocia G, et al. Mild hyperhomocysteinemia and the common C677T polymorphism of methylene tetrahydrofolate reductase gene are not associated with the metabolic syndrome in Type 2 diabetes. J Endocrinol Invest. 2006;29(3):201-7.

16. Roffeei SN, Mohamed Z, Reynolds GP, Said MA, Hatim A, Mohamed EHM, et al. Association of FTO, LEPR and MTHFR gene polymorphisms with metabolic 
syndrome in schizophrenia patients receiving antipsychotics. Pharmacogenomics. 2014;15(4):477-85.

17. Tang R, Liu H, Yuan Y, Xie K, Xu P, Liu X, et al. Genetic factors associated with risk of metabolic syndrome and hepatocellular carcinoma. Oncotarget. 2017;8(21):35403.

18. Chedraui P, Pérez-López F, Escobar G, Espinoza-Caicedo J, Montt-Guevara M, Genazzani A, et al. Polymorphisms of the FTO and MTHFR genes and vascular, inflammatory and metabolic marker levels in postmenopausal women. J Endocrinol Invest. 2016;39(8):885-90.

19. Chen A-R, Zhang H-G, Wang Z-P, Fu S-J, Yang P-Q, Ren J-G, et al. C-reactive protein, vitamin $\mathrm{B} 12$ and $\mathrm{C} 677 \mathrm{~T}$ polymorphism of N-5, 10-methylenetetrahydrofolate reductase gene are related to insulin resistance and risk factors for metabolic syndrome in Chinese population. Clin Invest Med. 2010;33(5):2907.

20. Fakhrzadeh H, Tavakoli J, Amoli M, Mirarefin M, Sharifi F, Ghotbi S, et al. Investigation of the Relation of Methylenetetrahydrofolic Acid MTHFR (C677T) Reduction Gene with Metabolic Syndrome in the Iranian Population: Tehran Homocysteine Study. ijdld. 2009;8(3):28998.

21. Kang BS, Ahn DH, Kim NK, Kim JW. Relationship between metabolic syndrome and MTHFR polymorphism in colorectal cancer. J Korean Soc Coloproctol. 2011;27(2):78-82.

22. Yang B, Fan S, Zhi X, Wang D, Li Y, Wang Y, et al. Associations of MTHFR C677T and MTRR A66G gene polymorphisms with metabolic syndrome: a case-control study in Northern China. Int J Mol Sci. 2014;15(12):21687-702.
23. Zeman M, Jáachymová M, Jirák R, Vecka M, Tvrzická E, Stankova B, g. Polymorphisms of genes for brain-derived neurotrophic factor, methylenetetrahydrofolate reductase, tyrosine hydroxylase, and endothelial nitric oxide synthase in depression and metabolic syndrome. Folia Biol. 2010;56(1):19.

24. Yamada Y, Kato K, Hibino T, Yokoi K, Matsuo H, Segawa T, Watanabe S, Ichihara S, Yoshida H, Satoh K, Nozawa Y. Prediction of genetic risk for metabolic syndrome. Atherosclerosis. 2007 Apr 1;191(2):298-304.

25. Ellingrod VL, Miller DD, Taylor SF, Moline J, Holman T, Kerr J. Metabolic syndrome and insulin resistance in schizophrenia patients receiving antipsychotics genotyped for the methylenetetrahydrofolate reductase (MTHFR) 677C/T and 1298A/C variants. Schizophr Res. 2008;98(1):47-54.

26. Gallou-Kabani C, Junien C. Nutritional epigenomics of metabolic syndrome. Diabetes. 2005;54(7):1899-906.

27. Lu Q, Qiu X, Hu N, Wen H, Su Y, Richardson B. Epigenetics, disease, and therapeutic interventions. Ageing Res Rev. 2006;5(4):449-67.

28. Waterland RA, Jirtle RL. Early nutrition, epigenetic changes at transposons and imprinted genes, and enhanced susceptibility to adult chronic diseases. Nutrition. 2004;20(1):63-8. 